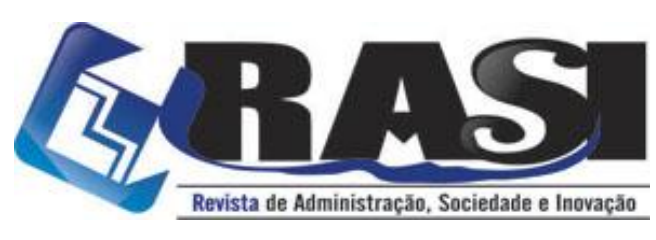

http://www.rasi.vr.uff.br

RASI, Volta Redonda/RJ, v. 6, n. 2, pp. 134-142, mai./ago. 2020

\title{
Particularities in financing tools: A case study of an Agency for Science, Technology and Innovation of Rio de Janeiro State, Brazil
}

\author{
Daniel Pereira de Almeida (UFRJ) - dpalmeida@id.uff.br \\ Thiago Borges Renault (UFRRJ) - thiagorenault@gmail.com \\ Gerd Brantes Angelkorte (UFRJ) - angelkorte@ppe.ufrj.br \\ Marcus Vinicius de Araujo Fonseca (UFRJ) - vfonseca@labrintos.coppe.ufrj.br \\ Sérgio Yates (UFRJ) - syatesbz@gmail.com
}

\begin{abstract}
This work aims to analyze the objectives and interactions of innovation financing tools from a point of view of a technology, research and innovation foundation. It brings as subject the case of the Technology, Research and Innovation Foundation of the State of Rio de Janeiro (FAPERJ), and its incorporation of a Technology Board. Working side by side with a Scientific Board, it faces the challenge of interact, finance, and boost innovation, whereas the Foundation carries more than 40 years of basic research funding (1980 until 2019) the financing of innovation activities was incorporated in 2002. With the R\&D activities in Brazil centered on public University, Research Institutes and only a small presence in companies (only 5\% of the innovative companies perform R\&D), FAPERJ's faces the challenge of create financing tools that improves the interaction between these actors. The sample analyzed in this study relates the eligibility criteria used in the FAPERJ's Technological Development Support (ADT) with similar and inspiring program, the United States of America Small Business Innovation Research (SBIR). As result, we have found the lack of incentives for interaction between universities and business sector, showing that only a small part of the projects financed by FAPERJ can reach the commercialization.
\end{abstract}

Keywords: Innovation; R\&D; Small Business; University; Triple Helix.

\section{Particularidades em ferramentas de financiamento: um estudo de caso de uma Agência de Ciência, Tecnologia e Inovação do Estado do Rio de Janeiro, Brasil}

\section{Resumo}

Este trabalho tem como objetivo analisar os objetivos e as interações das ferramentas de financiamento à inovação do ponto de vista de uma fundação de apoio à ciência, tecnologia e inovação. $\mathrm{O}$ assunto tratado é o caso da Fundação Carlos Chagas Filho de Amparo a Pesquisa, Tecnologia e Inovação do Estado do Rio de Janeiro (FAPERJ) e a incorporação de uma Diretoria de Tecnologia. Trabalhando lado a lado com a comunidade científica, a Fundação enfrenta desde 2002 o desafio de interagir, financiar e impulsionar a inovação, enquanto mantém mais de 40 anos de financiamento de pesquisa básica (1980 a 2019). Com atividades de P\&D no Brasil centradas em universidades públicas, institutos de pesquisa e apenas uma pequena parcela em empresas (apenas 5\% das empresas inovadoras realizam P\&D), a FAPERJ enfrenta o desafio de criar ferramentas de financiamento que melhorem a interação entre esses atores. A amostra analisada neste estudo relaciona os critérios de elegibilidade usados no Auxílio ao Desenvolvimento Tecnológico da FAPERJ (ADT) com um programa semelhante e inspirador, de apoio à Pesquisa de Inovação em Pequenas Empresas (SBIR) dos Estados Unidos da América. Como resultado, a despeito dos esforços desprendidos, observa-se a baixa interação entre universidades e setor empresarial, mostrando que apenas uma pequena parte dos projetos financiados pela FAPERJ pode atingir a comercialização.

Palavras-chave: Inovação; P\&D; Pequenas e médias empresas; Universidade; Hélice tríplice.

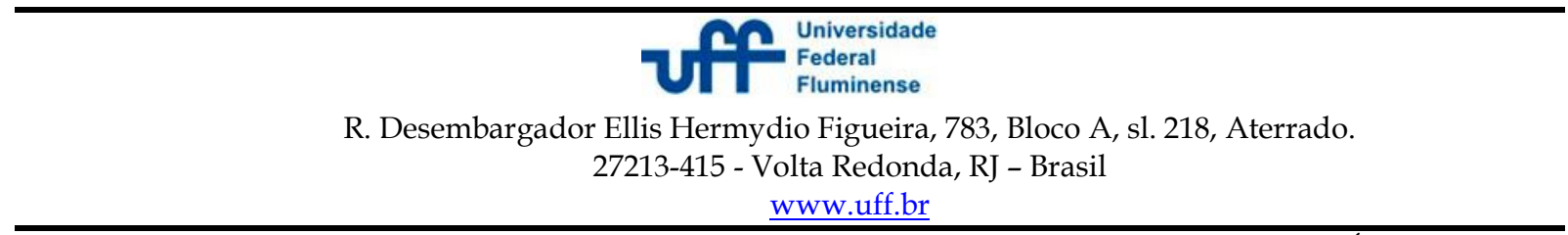

Copyright (C) 2020 RASI. Todos os direitos, até mesmo de tradução, são reservados. É permitido citar parte de artigos sem autorização prévia, desde que seja identificada a fonte. 


\section{Particularities in financing tools: A case study of an Agency for Science, Technology and Innovation of Rio de Janeiro State, Brazil}

\section{FAPERJ's operating context}

Brazil has a wide scientific production. According to the Clarivate Analytics report: Research in Brazil (Web of Science Group, 2019) between 2013 and 2018, occupied the 13th position in the world scientific production ranking, remaining behind United States, China, India, and others. As well, only $1 \%$ of these Brazilian's papers have the participation of at least one author from the private sector (Cross et al 2018).

The results of these isolated initiatives are reflected thought the innovation system (Longo, 2009). Innovation Survey in Brazil, PINTEC, shows the rate of innovative companies in Brazil from 2012 until 2014 was 36\% (IBGE, 2015). When analyzed the degree of novelty of these activities, merely $1 \%$ of these innovations were new for the world. As well, only $5 \%$ of these companies perform R\&D activities like systematic research activities, human resources development (training, academic training of masters and doctoral level staff, professional history, among others) and intellectual property (present in a large part of R\&D projects), essential for their innovation and development of state-of-the art technology (OECD, 2015). The innovation's levels in Brazil are extremely modest, occupying the 64th place on Global Innovation Index (2018) sponsored by Cornell University, The Business School for the World and World Intellectual Property Organization.

Although the initial guidelines for the public innovation policies have had a technological inclination, the actual model involves small connections between government, universities, private sector and vice versa. It results on isolated enterprise activities, where the innovations that are new for a region are barely considered. Most of time, it involves only improvements and/or acquisition of machinery and equipment for modernization. As well, projects developed only by scientists or researchers, even though involving $R \& D$, will not be considered an innovation if do not reaches the market. In this moment the public sphere must act, with fiscal and economic incentives and/or in the interaction of public and private sector, acting as inducer of socioeconomic development of countries and/or regions (Mazzucato, 2015).

\section{Brazilian interaction between Science, Technology and Innovation}

Brazil is divided into 26 states and one Federal District. Its public policies to encourage Science, Technology and Innovation (S,T\&I) may be federal, state, and in some cases municipal. The launch of the innovation law in 2004 was an important milestone in this journey. Formulated from an S\&T interface point of view, this policy addresses only a minor connection with business environment. At the federal level, Brazil operates through government agencies such as Studies and Projects Funding Agency (FINEP), National Council for Scientific and Technological Development $(\mathrm{CNPq})$ and the National Bank for Economic and Social Development (BNDES), which both are responsible for financing innovation projects. At the state level, it also operates through Foundations of Support to Research (FAP). There is no law obliging the creation of such mechanisms, however, the constitution encourages states to cooperate with budgetary resources complementary to those at the federal level. Every Brazilian state and the Federal District has its own FAP. Acting with a regional focus, the FAPs have the advantage of knowing the particularities of each 
state, enhancing its performance. This helps the creation of public policies closer to the reality of each region, leveraging its efficiency.

FAPERJ was the third FAP created in the country, made possible by Decree No. 3,290, dated June 16, 1980 (Governo do Estado do Rio de Janeiro, 1980). Its mission was defined as "to promote and support research and scientific and technological training necessary for the socio-cultural and economic development of the State".

By the year of 1989 FAPERJ was restructured, and its base was composed from a Scientific and Administrative boards. With the support of the local scientific community and the Constituent Assembly, in this year, it was enacted in the state Constitution, the allocation of $2 \%$ of net state tax revenue FAPERJ.

However, in the past ten years, a technological (not restrictive to innovation) demand began to arise specifically from theSectorial Policy for Technological Development of the State of Rio de Janeiro, and the creation of Municipal Funds to Support Scientific Research. In the year of 2002, the State of Rio de Janeiro introduced innovation on its agenda. The Secretariat of Science and Technology became known as the Secretariat of Science, Technology and Innovation. FAPERJ had a Technology Board created, being in Brazil the first FAP to have such board, assuming the role of Rio de Janeiro State promoter of innovation.

The following years were marked by the State Innovation Law (State Government of the Rio de Janeiro, 2008), which provides incentives for innovation, scientific and technological research in the environment of the State of Rio de Janeiro. Its main objective involve "approach of scientific and technological production to market needs and to promote integration between the academy, businesses and development agencies, contributing to the innovation process." Through this law, the FAPERJ was authorized to participate in the capital of private enterprises aimed at the development of scientific and technological projects to obtain product or innovation, granted in return for promotion.

The blandly new idea of innovation funding, whereas only a small percentage of the companies develop R\&D, was a tough task. The initial propose was to find a "successful" and in progress program that could be replicated. FAPERJ chose to learn from the neighborhood, and took as example the Business Research Support Program, the PIPE program from the São Paulo State Research Support Foundation - FAPESP. As well, this program was also based on another one, the SBIR program, the United States of America governmental seed fund.

As SBIR was taken as a model for the FAPERJ funding, it was decided to compare both programs contrasting its main differences. Is it possible for FAPERJ to replicate the SBIR results? Does the program fit the particularities of the state of Rio de Janeiro?

\subsection{SBIR and ADT financing tools}

Despite the creation of the Technology Board in 2002, FAPERJ began funding technology (not strictly innovation) development since 1990. However, the first edict from this Board, with exposed mention to innovation was the Rio Innovation I, in partnership with FINEP and Ministry of Science and Technology under the Program for Research Support in Companies. From this experience, in 2007, FAPERJ's Technology Board integrates a mechanism similar to FAPESP PAPPE, Program to Support Research in Small Businesses and SBIR programs to its agenda, being called of Technological Development Support (ADT 1) and Insertion of New Technologies in the Market Support (ADT 2) (first editions on 2007 and 2013 respectively). 
The sample to be analyzed in this study, is related to ADT 1 and ADT 2 programs involving public edicts released from 2013 until 2016 by the Technology Board since its establishment. Owing to the financial problems faced by the State of Rio de Janeiro, the years from 2017 to 2019 do not count with ADT editions.

The eligibility data from ADT and SBIR are public, and were collect from both websites (www.faperj.br for ADT and www.sbir.gov for SBIR). The funding amounts from SBIR may be, as well, obtained from this website, however, ADT's data was not detailed, and required a formal contact asking for this information. Due to the phase method similarity, this data was compared with SBIR programs target audience and conditions of eligibility. However, it worth mentioning that FAPERJ's programs works only on the State of Rio de Janeiro, when SBIR has a countrywide range. This fact may influence when comparing the amount invested, but is still considerable when comparing the percentage dedicated to each program.

As reference, this topic brings some information related to the ADT 1 and ADT 2 FAPERJs programs, as well SBIR Phase I, II and III:

- ADT 1: This program objective is to support Technological Innovations projects in Products and Processes (TPP) (OECD/Eurostat/EU, 1997), conducted by a developer or company with experience in the execution of new technology-based or innovative projects at a regional and national level;

- ADT 2: This modality is intended for dissemination and / or commercialization of research results or development that received FAPERJ support, whether in the form of products / services ready for commercialization, whether in the form of technologies to be transferred. It may possibly include intellectual property protection activities.

The SBIR program has the objective of create an interaction between small business and Federal Research/Research and Development (R/R\&D) with commercial potential. The program has three Phases, where each one is meant to fit the small business stage:

- Phase I: Introductory stage, where small business studies the R/R\&D commercial potential, viability and merit. The maximum provided is $\$ 150,000$ for six months. Depending on the stage of development, some projects can skip this phase, proceeding directly to Phase II;

- Phase II: This phase is based on the scientific and commercial potential results achieved on Phase I, or already owned by the small business (when Phase I is skipped). This stage can awardees a maximum of $\$ 1,000,000$ for two years;

- Phase III: The objective of this phase is the commercialization. SBIR program will not fund from this step. However, Federal agencies may be interested and involve followon non-SBIR funded.

\section{Relationship between SBIR and ADT}

Despite similarities in its phase model, SBIR and FAPERJ differs themselves very much in the selection criteria and objectives. As shown above, the ADT program does not have many restrictions and is open to the vast majority (if not all) of proponents. Table 1 compares both programs, similarities and divergences: 
Table 1. Comparing SBIR and ADT eligibility criteria

\begin{tabular}{|c|c|c|c|c|c|}
\hline \multirow{2}{*}{ ELIGIBILITY } & \multicolumn{3}{|c|}{ SBIR } & \multicolumn{2}{|c|}{ ADT } \\
\hline & PHASE I & PHASE 2 & PHASE 3 & ADT 1 & ADT 2 \\
\hline Project involves R\&D & $\begin{array}{l}33 \% \text { may be } \\
\text { subcontracted }\end{array}$ & $\begin{array}{l}50 \% \text { may be } \\
\text { subcontracted }\end{array}$ & No restriction & No restriction & No restriction \\
\hline $\begin{array}{l}\text { Small for-profit } \\
\text { business applicant }\end{array}$ & Mandatory & Mandatory & Mandatory & No restriction & No restriction \\
\hline R/R\&D Institution & Mandatory & Mandatory & Mandatory & No restriction & No restriction \\
\hline $\begin{array}{l}\text { Maximum public } \\
\text { funding }\end{array}$ & US 150,000 & US $1,000,000$ & Not allowed & No restriction & No restriction \\
\hline Max execution time & Six months & Two years & Not specified & Two years & Two years \\
\hline
\end{tabular}

Source: FAPERJ (2019); SBIR (2019)

The first point to be questioned is regarding to the interaction and presence between $\mathrm{R} / \mathrm{R} \& \mathrm{D}$ and small business in the projects. According to SBIR: it is mandatory that the project is submitted by a company; and involves $R / R \& D$. Small businesses, due to high costs, lack of $\mathrm{R} / \mathrm{R} \& \mathrm{D}$ centers but may seek partnerships, research centers or companies that possess these skills. However, the ADT, leaves these criteria open, allowing entry of various bidders. As it does not require the presence of $\mathrm{R} / \mathrm{R} \& \mathrm{D}$ in the projects, it also allows projects with low/none technology to apply, and eventually, receive funding.

The second point is related to the amount financed and the execution time. Being operated in a lean way, SBIR funding depends on the Phase. These restrictions allow the basic projects to be approved/disapproved in a faster way, accelerating their transition. Similarly, the program directs its energies and financial resources for Phase II, where the funds are much more generous. The only existing restriction on ADTs 1 and 2 is the run time of up to two years without establishing a maximum limit for the amount to be financed.

An existing requirement in both models (SBIR and ADT) is the relationship between the first and second phases. Both require projects to be sequenced or transition from one phase to the next.

\subsection{Conversion rate for the projects}

Not every project is successful, especially when it involves uncertainly (OECD, 2015). However, the funding agency must have mechanism and rules that increases the odds of the investment return (taxes, employments, social impacts, etc.) In both cases, this can be measure through the conversion rate: Phase II for SBIR, and ADT2 for ADT. Despite this is not a "sure goal", it can work as a measure, showing better results at the earlier stages.

When comparing the conversion rates for the next phases, it is questionable as FAPERJ can encourage that projects reach this stage.Figure 1 describes the quantitative and percentage of projects awarded per stage. 
Figure 1. Amount and percentage of projects awarded per stage
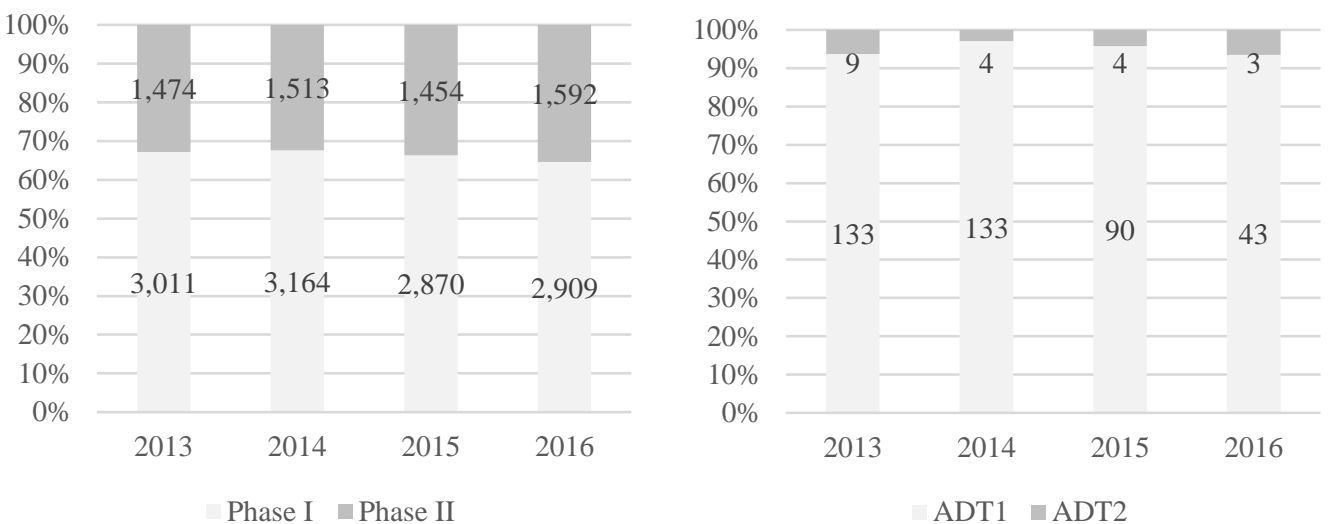

Source: FAPERJ (2019); SBIR (2019)

With a considerably small amount of projects awarded in ADT 2, the expectation success rate in commercialization are even smaller. The biggest problem on FAPERJ's ADT is the lack of encouraging interaction among agents. On the one hand, researchers with experience in $\mathrm{R} / \mathrm{R} \& \mathrm{D}$, but without interaction with companies develop research projects, which may or may not be introduced in the market. On the other, companies with no R/R\&D infrastructure, individually seek solutions without research institutes support (competence in scientific and technological knowledge), hindering the implementation of quality innovations involving technology. If FAPERJ funding models do not encourage interaction between companies, S,T\&I institutions, as well as research centers, hardly it will reach best position for innovation rankings. It's not just an amount of funding, but also forms of use (Quintal \& Terra, 2014).

From another perspective, it worth to mention the amount invested in the projects. Despite the ADT2 have no maximum investment solicitation, its values are significantly different from SBIR Phase II. The amount invested from both programs can be seen of Figure 2:

Figure 2. Amount in thousands of dollars and percentage of projects awarded per stage
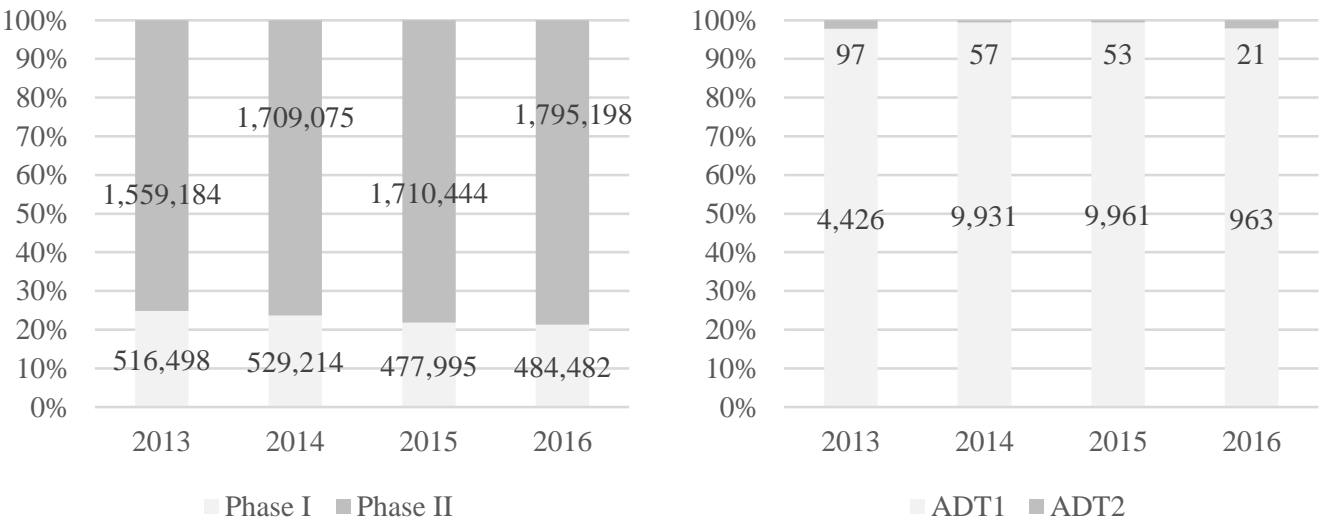

Source: FAPERJ (2019); SBIR (2019) 
This reflects not only the small number of projects funded in ADT2, but as well, it shows, once again, a small conversion rate. When SBIR focus its investments in Phase II, with at least $70 \%$ of the budget, ADT can't reach $10 \%$ of this amount.

\section{Divided Axis}

The model applied by FAPERJ does not fit the reality of the State of Rio de Janeiro. With a considerable scientific production rate, but a small innovation taxes, it faces difficulties in developing their public policies. The similarities seen between programs show that the model adopted by FAPERJ, the ADT, is not appropriate. It is not aiming the main problem: lack of interaction between the propellers - industry, academia and government. As a result, the axis of companies and universities end up adopting independent paths. With FAPERJ, representing the axis "government", it ends up being divided in the performance of the two boards: Scientific and Technology. By one side, scientific projects are developed in isolation, without any interaction with the market. It becomes doubtful that these research projects will reach commercialization, becoming innovations. Despite the expectations, a development agency that has acted for more than 40 years with scientific production strengthens little the transfer of this knowledge to the market. On the other side, with very comprehensive criteria, the Technology Board acted in dispersed form. It lack directed investments in the interaction between the axis of the triple helix. In fact, its performance is more focused on financing companies, innovative or not, and involving R\&D activities (OECD, 2015) or not. It should be noted that non-innovative projects, whose involve risk and not uncertainty, can obtain financing in public or private banks (even if exposed to interest and exorbitant guarantees), and it is not the competence of a Development Agency to operate in this sector.

A state reflection is required to this issue. Being a developing country, Brazil has prominent scientific community, and a little exploration of its applicability.

\section{Amendments Required}

This study shows the results of isolated and heterogeneous interactions made by FAPERJ. Through this research, it was possible to identify problems in the financial model used by the agency. Compared with SBIR program, many lessons should be taken before applying in the Rio de Janeiro State, in Brazil. By consulting actual and previous instruments, it was possible to analyses the specificity and particularity of science, technology and innovation financing tools. These conclusions reflect the strategic decisions taken by FAPERJ in financing models, its history of financing S\&T activities and its mission of encouraging technological innovation projects.

Faced up to low innovation rates, the Foundation chose to be more generic, and opened up selection criteria, allowing isolated actors to be fund. As a result, the synergies between scientific and innovation activities were not explored, generating impacts on the governance of the process. With a small, and sometimes, no conversion rate of ADT1 project to ADT2, it is doubtful the program mechanism. Even with only a few restrictions, a single part of ADT1 projects are eligible for ADT2. This may be the result of poor (or non) technological or only conceptual projects, resulting most of times, in failure.

Therefore, as well, it is questioned the agency efficiency on impacting substantially technological innovation the same way it did for the scientific community over the past years. Being developed through a Research Funding Agency, FAPERJs mission with innovation is even harder to be achieved. If the government do not work to develop tools and mechanisms 
to improve its interaction, Brazil will remain only scientific focused, and innovation will remain to be set aside.

\section{References}

Brasil.Law $\mathrm{n}^{\circ}$ 10,973, December 02 (2004). Provides for incentives to innovation and scientific and technological research in the productive environment and provides other measures. Diário Oficial [da] República Federativa do Brasil. Brasília, DF, December 03 (2004).

Cross, D.; Thomson, S.; Sinclair, A. (2018). Research in Brazil: a report for CAPES by Clarivate Analytics.Clarivate Analytics. Retrieved April 01, 2019, from https://www.capes.gov.br/images/stories/download/diversos/17012018-CAPESInCitesReport-Final.pdf.

Governo do Estado do Rio de Janeiro. Decree no 3,290, June 16 (1980). Createthe Fundação Carlos Chagas Filho de Amparo à Pesquisa do Estado do Rio de Janeiro (FAPERJ). Retrieved April 01, 2019, from http://www.faperj.br/downloads/decreto_3290.pdf.

Governo do Estado do Rio de Janeiro. Decree $n^{\circ}$ 5,361, december 29 (2008). State Innovation Law.RetrievedApril 01, 2019, fromhttp://www.faperj.br/?id=1125.3.0.

IBGE. (2015). Pesquisa de Inovação (PINTEC). In Pesquisa de Inovação 2014. https://doi.org/ISSN 0101-4234.

Longo, W. P. (2009). De um passado glorioso a um futuro brilhante. Inovação em Pauta, n. 7, RetrievedApril 01, 2019, from http://www.finep.gov.br/images/revistas-finep/edicao763/index.html>.

Mazzucato, M. (2015).The entrepreneurial state: Debunking public vs. private sector myths.

OECD. (2015). Frascati Manual 2015: Guidelines for Collecting and Reporting Data on Research and Experimental Development. In The Measurement of Scientific, Technological and Innovation Activities. https://doi.org/10.1787/9789264239012-en.

OECD/Eurostat/EU. (1997). Proposed Guidelines for Collecting and Interpreting Technological Innovation Data (OECD). https://doi.org/10.1787/9789264192263-en.

Quintal, R. S., \& Terra, B. R. C. dos S. e S. R. (2014). Políticas organizacionais de ciência, tecnologia e inovação e gestão da propriedade industrial: uma análise comparativa em Instituições de Pesquisa. Gestão\&Produção. https://doi.org/10.1590/0104-530x1053/13.

Web of Science Group. (2018). Research in Brazil: Funding excellence. Retrieved October 12, 2019, from https://jornal.usp.br/wp-content/uploads/2019/09/ClarivateReport_20132018.pdf.

World Intellectual Property Organization (2018).Global innovation index 2018: energizing the world with innovation. Ithaca, Fontainebleau and Geneva: Cornell University; 
TheBusiness School for the World; World Intellectual Property Organization. Retrieved April 01, 2019, from https://www.globalinnovationindex.org/home. 